\title{
Actualization of Mataraman society virtues on life
}

\author{
N.W. Rochmadi* \\ Universitas Negeri Malang, Malang, Indonesia
}

\begin{abstract}
Mataraman is the term for the Javanese elite community, which models for the Javanese character. This research aimed to describe the actualization of the virtues in life. The research was conducted with a descriptive qualitative research design. Data collection techniques used observation, interviews, and study documentation. Data was analyzed using the interactive model. Research findings were (1) the mataraman society virtues were: (a) simplicity, (b) respect for others and parents, (c) introspection, mawas diri, nandhing sariro, ngukur sariro, tepa saliro, mulat saliro, (d) gemi, nastiti, ati-ati, (e) harmony, (f) surrender to God, (g) wisdom, and (h) humbleness; (2) actualization of the virtues in life with language, use of words, volume and intonation, behavior (gerak laku), clothing (busana), leadership in the family, and traditions. Based on the research findings, be suggestions: (a) make the virtues as a guideline in behavior; (b) used to behaving in accordance with the virtues.
\end{abstract}

Keywords: actualization, virtues, Mataraman

\section{INTRODUCTION}

Human life cannot be separated from groups, society, nation, and state. Through groups, humans express and try to realize their ideals in life, one of its forms is by creating a culture. Culture is a reflection of human life in reality and ideals.

Human cultural life in social, national, and state activities is manifested based on ideal values or virtues. Therefore, every community always has virtues, which serve as guidelines for their behavior in realizing a better life. The virtues of the community are manifested in the form of various rules of life in society, in the form of norms that become the order and reference in interacting with others and with the environment.

Each individual is controlled by the norms (rules) of the society, nation, and state. Basically, the existence of norms in human life aims to protect and care for faith or belief in God, respect and appreciate individual values, which are honor and must be respected by everyone, sustain life, carry on offspring and maintain ownership which is a gift of God earned through work.

Humanity in culture is manifested in the form of social, national, and state activities, through a social contract or collective agreement, referring to the virtues of the nation and norms. Being a society and nation and state are human instincts, as social beings, and for people who are religious, at once are orders from God. However, different from the gathering of animals, humans come together and create a better life by referring to virtues such as justice, security, welfare, deliberation, and peace. In the context of Indonesia, these virtues are formulated in a value system consisting of five principles, called Pancasila, namely Ketuhanan Yang Maha Esa, Kemanusiaan yang Adil dan Beradab, Persatuan Indonesia, Kerakyatan yang dipimpin oleh Hikmat Kebijaksanaan dalam Permusyawaratan/Perwakilan dan Keadilan Sosial bagi seluruh Rakyat Indonesia. On the basis of these five principles, all Indonesian people unite and live together on the basis of the principle of kinship within the unitary state of the Republic of Indonesia.

\footnotetext{
${ }^{*}$ Corresponding Author
} 
Be society and state are regulated by an authority established through noble agreements and agreements in the form of norms. Regulations in the form of norms are aimed at ensuring the achievement of good and absence of bad and evil in life together, as well as being the mission of the state authority.

As in state life, social and national life also refers to virtues that are shared in their truth. These virtues become a reference in shaping the order of life in society and as a nation and state. The virtues and order become a reference in the behavior of the supporting community in interacting with others and with their natural environment. The ownership of behavior in accordance with the values and order of society is what ultimately becomes the identity of the communities concerned, one of which is the Mataraman community.

Based on the Javanese structure, Javanese ethical values serve as a guide for Javanese people when they do activities and interact with fellow humans in the life of the state and society. These Javanese ethical values are contained in an order known as the unggah-ungguh. The Javanese ethical values and unggah-ungguh are used as guidelines for behavior when interacting with fellow humans, and the environment.

Mataraman is a portrait of the ideal and role model of Javanese society, although among them there are still further groupings and have various characteristics. However, they are a group of Javanese people who are consistent in obeying and implementing Javanese ethical values and structures. Based on this, an exploratory study was conducted on the virtues of the Mataraman community and their actualization in they life.

\section{METHODS}

In accordance with the objectives, this research was conducted with a descriptive qualitative design. The researcher conducted an exploratory study on the actualization of the virtues of the Mataraman community in Blitar City. The data sources of this research are those who understand the virtues of the Mataraman community in the Blitar City, including Sujilah, Totok, Mardiono, Purnaningsih, Willis Purwanto, Setyo Winarno, Sutadi and Dyah Palupi. Data collection was carried out by observation, interviews, documentation, and focus group discussions. The data analyzed refers to an interactive model from Miles and Hubermans.

\section{RESULTS AND DISCUSSION}

\subsection{The virtues of the Mataraman society}

The Mataraman society is a Javanese community that socially and culturally has a relationship with the influence of the Kerajaan Mataram culture, from the Hindu-Buddhist era to the Mataram Sultanate era which was centered in Yogyakarta and Surakarta. The existence of the mataraman community around the city of Blitar is a necessity. The existence of the Mataraman community in the city of Blitar is related to the history of the Javanese war (De Java Oorlog), the war against the Dutch (VOC) led by Pangeran Ontowiryo (Pangeran Diponegoro) between 1825-1830 (Moedjanto, 1987).

The defeat of Pangeran Diponegoro in the Java war resulted in those who became Laskar Diponegoro fleeing from the Yogyakarta area to all corners of Java, including to Blitar, by disguising themselves, opening new hidden land, staying as magersari (hitching a ride in someone else's yard or living land owned by the state while cultivating the land). Laskar Diponegoro, who fled to Blitar, grew and developed to form its own villages in several areas around the city of Blitar, the area called Kampung Mataraman, said Mr. Mardiono.

Based on the Javanese norms, Javanese ethical values should serve as a guideline for Javanese people when they do activities and interact with fellow humans in life, as well as in society. These Javanese ethical values are contained in an order known as unggah-ungguh. Javanese humans who implement Javanese virtues are given as wong mbeneh or people who have virtues, if their behavior 
is not in accordance with these values then it is called wong ora mbeneh. The statement is in accordance with that delivered by Mr. Mardiono, "Tiang jawi meniko kedhah mbeneh. Tiang jawi meniko kedah manut kaliyan ugi ngikut dateng tatanan lan budaya jawi".

Likewise, what was conveyed by Mr. Totok as a descendant of Mataraman and a teacher by profession, "Javanese people, especially Mataraman, must be good, have virtues. His daily behavior in interacting with fellow humans must be in accordance with the Javanese culture and order." $\mathrm{He}$ further said that "If humans can behave in accordance with Javanese culture, Javanese virtues, it is believed that they will find lahir batin safety in their lives, both themselves and their families".

According to Mr. Mardiono, "The characteristics of the Javanese Mataraman are simple, harmonious and introspective, including nandhing sariro, ngukur sariro, tepa saliro, mulat saliro." Meanwhile, Mr. Totok stated that "Mataraman people have high respect for parents, are simple, wise, humble and not arrogant, it can be seen from the house, simple from the outside but luxurious inside. In addition, Mataraman people usually have a high surrender to God."

Meanwhile, according to Mrs. Sujilah, "The mataraman people usually even nopo wontene, atosatos uripe, rukun kalih liyane, khurmat kaliyan sapodho-podho have a sense of wedi, isin, sungkan to others; fear of prayer; takut kuwalat; andhap asor; ngapuracang; sendiko dhawuh; sabar lan narimo, pasrah lan sumeleh; percaya akan pepesthen, jodho, rejeki, pati garise pengeran. eling sangkan parane dumadi".

The above statement was approved by Mrs. Purnaningsih (wife of the Mataraman resident), "Bapak kulo meniko dalang, saben-saben tansah maringi pitutur luhur; dedalane guna lawan sekti iku kudu andhap asor, wani ngalah luhur wekasane, tumungkulo yen dipun dukani, bapang den simpangi, ana catur mungkur, mbangun turut". It means that in order for us to be useful or successful people, we must behave politely to people. Otherwise, not being arrogant, placing others higher, respecting others in relationships, daring to give in and yielding does not mean losing, being able to control oneself, not fighting back, looking down when wrong and being scolded, accepting input from others, avoiding things that not good, not extravagant, simple, and avoiding fighting, gossip, and prejudice are also necessary.

These values are the identity of the Mataraman community, manifesting themselves as true human beings. Besides that, it is also a reference in realizing an ideal life as a Javanese man who is physically and mentally prosperous. The virtues possessed by the Mataraman society above are in line with Javanese manners as revealed by the Yogyakarta Province Character Development Team as follows: (1) dedication; (2) honesty; (3) courtesy; (3) tolerance; (4) discipline; (5) sincerity; (6) responsibility; (7) harmony; (8) politeness (tepa selira); (9) self-awareness (papan, empan, adepan); (10) manners (tata krama); and (12) mutual cooperation (gotong royong) (Supriyoko 1996).

Meanwhile, according to Endraswara (2016) the essence of Javanese culture is "Javanese people believe in and take refuge in the God, the cause of all life, the existence of the world and the whole universe, the beginning and the end; Javanese people are harmonious in peace, harmonious (rukun), orderly in their birth and peaceful in their mind, noble and human beings".

Based on the explanation above, virtues of the Mataraman community are: (1) simplicity, (2) respect for others and parents, (3) politeness, (4) frugality and caution (gemi, nastiti, ati-ati), (5) harmony, (6) surrender to God Almighty, (7) prudence, wisdom, and (8) humbleness.

The virtues of Javanese culture developed by the Mataraman community are no different from the focus of developing the character of the Indonesian nation which lies in six values, namely three personal dimensions (honesty, common sense, and courage), and the other three social dimensions (fair, responsible, and tolerant). If the development of these six values is truly developed in a professional and national scope, it is not impossible that an increase in the quality of Indonesian people within one generation will occur (BSNP, 2010). In terms of instilling the values of Javanese character values, Javanese character includes taqwa, remembering of God, tawakal, repentance, shame, fairness, respect for others, sincere, patient, honest, kind, forgiving, helpful, grateful, wise, benevolent, brave, officer and loyal, then the tim pengembang budi pekerti (TPBP) province DIY stated Javanese character includes: devotion, honesty, courtesy, tolerance, discipline, sincerity, responsibility, friendship, tepasaliro, small board, manners, and gotong royong (Supriyoko; 2000). 
Another opinion about the character that needs to be developed in Indonesian society was expressed by Megawangi, according to him, there were nine noble attitudes instilled from an early age in Indonesian children at school. These attitudes are: (1) love of God and truth, (2) responsibility, discipline and independence, (3) trustworthiness, (4) respect and courtesy, (5) compassion, care, and cooperation, (6) trust self, creative, and never give up, (7) justice and leadership, (8) kind and humble, and (9) tolerance and love peace. Then, other characters that need to be developed are "productive" and "creative/innovative" characters in thinking and working (Megawangi, 2004).

\subsection{The actualization of the Mataraman society virtues}

Actualization means the manifestation or showing of ownership of something. In the context of this study, actualization is showing the ownership of values in the form of Mataram society behavior, such as speech, attitudes, appearance, and actions.

Thus, the actualization of the virtues of the Mataraman community in their daily lives is manifested when they interact with each other through communication, appearance, attitudes and actions while in the family, community and during educational activities and at work. This is in accordance with the opinion of Spencer-Oatey (2004) that society's culture reflects the values of politeness and character as cultural products that are realized in the way of speaking and behaving.

The actualization of Javanese cultural virtues in the above manner has been conveyed by Gertz (1985) that Javanese children learn the principle of respect through 3 situations, namely wedi, isin, and shy. Wedi or fear, most Javanese children carry out the orders and prohibitions of their parents at first with fear. Isin or is called the culture of shame, shy is defined as doing everything that is not with sincerity, doing it only because of feeling bad for those who rule. The practice of character education by cultivating a sense of wedi, isin, and reluctance is very effective in developing children's character to behave in accordance with the noble Javanese cultural values.

Simple value actualization in the Mataraman community is manifested in the form of the appearance of the house where they live, the characteristics of the Mataraman community house in front are very simple but very luxurious inside. The mataraman family house tends to appear closed when viewed from the front, the house materials are very good, the door is in the style of butterfly fighting (model kupu tarung), the cleanliness of the house is well maintained and always maintained. Likewise, in dress, as said by Mrs. Sujilah as "Ndhuk yen nggawe rok aja cingkrang cingkrang, saru lho, lan ora usah macak sing aneh aneh, prasaja ae."

The actualization of the value of respect for others, especially parents, according to the statement of Mr. Willis Purwanto (a relative of Mataraman) that "Kagem tatanan jawi kurmat kaliyan tiyang sepuh puniko sanget utami, awit sanget mboten mapan pantes menawi ningali wonten lare-lare nungkak krama kalihan tiyang sepuh, menapa malih menawi ngantos mboten gadhah wedi kalihan tiyang sepuh, mboten duwe isin yen gadhah kalepatan, mboten sungkan nglampahi ingkang kirang sae, waah kedadosanipun nggih dados lare kurang ajar."

The actualization of the value of respect for parents is most evident in the tradition of sungkeman. Tends to Mrs. Sujilah As follows, "Sungkeman menika ajeg saben ba'da utaminipun, nanging sampun mboten kados rumiyin. Menawi kulo rumiyin taksih laku dhodhok, sakmeniko sampun mboten." The custom in the Mataraman family is that every family gathers, in turn, from the old to the young, to hold prayers, to forgive each other and most importantly to ask for prayers from the mother and father.

In addition, in terms of decision making, in various areas of life, the Mataraman community has great respect for parents, as said by Mrs. Purnawati (50 years old) as follows, "Yen babagan sing gegayutan karo keputusan kuwi bapakmu le, mengko ibu bisa keno duko." The child's trust in the father is very different from that of the mother. Children are more afraid and obedient to the father. What the father said, usually followed by the child and wife. There is a saying "Yen ora manut tak aturke bapakmu lo." The tendency in reciprocal interaction between the child and the mother uses the Javanese language ngoko, while with the father uses the kromo language.

Actualization of God values (ketuhanan), trust and devotion to the God through the tradition of salvation, ngampirne neton, by means of njenang abang, buceng kuat, brokohan. As said by 
Mr. Setyo Winarno: "Slametan meniko sae awit budaya, nanging kulo tansah nyuwun dhateng masyarakat sampun ngantos ukawis-ukawis donga mboten nerak wewaler agami, umpami menawi rumiyin nyenyuwunipun dumateng cikal bakal utawi dhanyangipun, nanging sakmeniko nyenyuwunipun tumuju dhateng Gusti Ingkang Maha Kuwaos dene para leluhur ingkang sampun sumare dipun suwunaken pangapuntun supados anggenipun kondur dhateng Pangayunaning Gusti saged diapuro sedaya dosanipun, kaparingan papan ingkang sekeco." That is what Mr. Sutadi (a resident of Mataraman) conveyed, as follows "Wonten tlatah kulo meniko taksih nguri nguri budaya, tradisi ugi taksih dipunlenggahi, biasanipun amargi meniko tradisi slametan kajatan meniko taksih glenggahi, slametan taksih wonten, sajen kajatan slametan taksih wonte."

The basic character that becomes the foundation of the Javanese is the nrimo attitude (Endraswara, 2016). Nrimo is accepting everything with spiritual-psychological awareness, without feeling ngrundel (grumbling). Whatever is accepted sincerely (paringane sing kuwasa). For self-control, as said by Mr. Sutadi, when giving his son advice when choosing one of the jobs, "Wis to le ditampa ae, nrima paringane sing kuwasa, aja nganja anja sing sumeleh." This attitude shows the guidance of patience associated with the garis pepesthen yang maha kuasa.

The cultural values of introspection, mawas diri, nandhing sariro, ngukur sariro, tepa saliro, mulat saliro, are manifested in associations with fellow humans starting from the family, an attitude of rasa rumangsa, tepa salira are instilled, which is often done in symbol language, under certain circumstances. it is enough to use the symbol to put the index finger on the mother's mouth. For example, when the father is sleeping, the mother puts her forefinger in her mouth while saying, "Huss aja gojek, bapak sare, mundhak kebribenan."

The manifestation of the values of gemi, nastiti, ati-ati, arif, dan rendah hati is done when doing something must be calculating and careful, not careless. This statement is in accordance with the narrative of Mr. Setyo Winarno (a resident of Mataraman Village) "menawi tiyang gesang meniko kedhah geni lan ati-ati supados slamet lan tenterem uripe, kaliyan sesame inggih kedah rendah hati".

The manifestation of the value of harmony is carried out by giving expressions such as those conveyed to others such as "To achieve success one must be harmonious;" crah agawe bubrah; rukun agawe santosa, and so on. The actualization of the virtues of the Mataraman community is manifested through communication using the right language, as conveyed by Mrs. Endah, "Actualization of Javanese language and trapsila there are two things that cannot be separated between Pocap and Patrap must be harmonious and balanced." Pocap is a choice of words that are spoken verbally and Patrap is a balance of past behavior when saying a word. For example, when the child says the word "Inggihm," it must be accompanied by the head bowing, the body half bent, hands ngapurancang.

The actualization of the virtues of the Mataraman society is also manifested in the form of various expressions, which are used as guidelines for people's behavior, to live side by side in harmony, harmony and balance between the life of the world and the hereafter. Balancing life in harmony with the environment or conditions that are happening. Besides that, it can also be used as a control to behave well in human relations with fellow humans, humans with the environment, and humans with God.

Based on the explanation above, the actualization of the virtue of the Mataraman community in everyday life is manifested in the form of patterns of use of language and attitudes when communicating with others, personal appearance and place of residence, attitudes and actions when interacting with others in various activities both during at home, in the community and at work.

\section{CONCLUSIONS}

There were eight virtues of the Mataraman society. They were simple, respect for others and parents, introspection or selfawareness, frugal and careful, harmonious, surrender to God Almighty, wise, and humble. Actualization of the virtues in life with language, use of words, volume and intonation, behavior, clothing, leadership in the family, and traditions. Based on the research findings, be 
suggestions for making the virtues as a guideline in behavior and behaving in accordance with the virtues.

\section{REFERENCES}

BSNP. 2010. Paradigma pendidikan nasional abad XXI. Badan Standar Nasional Pendidikan. Jakarta. Depdiknas.

Endraswara, S. 2016. Budi pekerti Jawa. Cakrawala. Jogjakarta.

Geertz, H. 1985. Keluarga Jawa. Gratifi Pers. Jakarta.

Megawangi, Ratna. 2004. Pendidikan karakter: Solusi yang tepat untuk membangun bangsa. Cimanggis: Indonesia Heritage Foundation.

Moedjanto. G. 1987. Konsep kekuasaan Jawa. Kanisius. Jogjakarta.

Supriyoko, K. 1996. Budi pekerti sebagai syarat kelulusan. Jogjakarta: 19 Mei 1996.

Spencer, H. \& Oatey.T. 2004. Culturally speaking: Managing rapport through talk across culture. 